\title{
A spontaneous interchange heterozygote mosaic in the grasshopper Stauroderus scalaris: interchromosomal chiasma effects
}

\author{
J. Cabrero and J. P. M. Camacho
}

Departamento de Genética, Facultad de Ciencias, Universidad de Granada, 18071 Granada, Spain.

\begin{abstract}
In a population sample of 74 individuals of the grasshopper Stauroderus scalaris a single male proved to be a heterozygous mosaic for an interchange involving unequal segments of the $L_{1}$ and $S_{8}$ chromosomes; one third of its testis follicles carried the mutation. Chiasma formation in the $S_{8}$ failed frequently thus leading to formation of chains of three plus one $S_{8}$ univalent. Whilst a reduction in chiasma frequency was observed in the long arm of the $L_{1}$ in all types of multiples, an increase in chiasma frequency of the bivalents not involved in the interchange was observed in cells with chains of three plus one univalent compared to those with multiples of four, so that total cell chiasma frequency remained constant. In all cells carrying the interchange, the orientation of the multiple was consistently non-disjunctional and so is expected to lead to gametic imbalance.
\end{abstract}

\section{INTRODUCTION}

Spontaneous interchanges are not infrequent in grasshoppers but they are not known to form polymorphisms (Hewitt, 1979). One factor contributing to this is undoubtedly the predominance of acrotelocentric chromosomes in the group. Interchanges between such chromosomes require simultaneous chiasma formation in translocated and interstitial segments for multiple formation, and chiasma formation in the interstitial segments produces imbalance in half of the meiotic products independently of multiple orientation (e.g., John, 1983). However, even in a whole arm interchange between two of the metacentric chromosomes in Gomphocerus sibiricus, which was characterized by the absence of interstitial segments, the multiple rarely oriented alternately (Gosálvez et al., 1982).

Interchanges usually modify chiasma formation in the vicinity of the exchange. This, it has been suggested, stems from pairing failure around the break points (Burnham, 1962; Sybenga, 1972, 1975). Additionally, inter-chromosomal effects of interchanges on chiasma formation have sometimes been found in grasshoppers (White, 1963; Hewitt, 1967; Arana et al., 1980) though only in cases where comparisons were made between cells from different individuals, so that the possibility that the differences were due to genotypic influence cannot be excluded.

In this paper we analyse one male of Stauroderus scalaris which was heterozygous for a very unequal interchange between the longest $\left(L_{1}\right)$ and the shortest $\left(S_{8}\right)$ members of the karyotype. The mosaicism of this individual allows us to compare cells with and without the interchange which possess the same genotype while the use of the $C$-banding technique facilitates the precise identification of the different regions of the multiples formed at meiosis.

\section{MATERIALS AND METHODS}

Forty-eight males and 26 females of the grasshopper Stauroderus scalaris were collected from a population at Trevenque (Sierra Nevada, Granada, Spain). Testes were fixed in 1:3 acetic ethanol while females were injected with 0.05 per cent colchicine in insect saline 6 hours before fixation of ovarioles. All fixed material was analysed by the $C$-banding technique, which was performed as follows: squash preparations were made in 45 per cent acetic acid and coverslips were removed 
by the dry ice method. The slides were subsequently immersed in $0.2 \mathrm{~N} \mathrm{HCl}$ at $20^{\circ}$ for 30 minutes, in saturated $\mathrm{Ba}(\mathrm{OH})_{2}$ at $60^{\circ}$ for 35 minutes and in $2 \mathrm{XSSC}$ at $60^{\circ}$ for 1 hour. Staining was carried out in 5 per cent Giemsa for about 2 minutes, and preparations were mounted in DPX.
RESULTS

Chromosome complement and nature of the interchange

The standard chromosome complement of Stauroderus scalaris consists of $2 n \hat{\delta}=16+\mathrm{XO}$ and

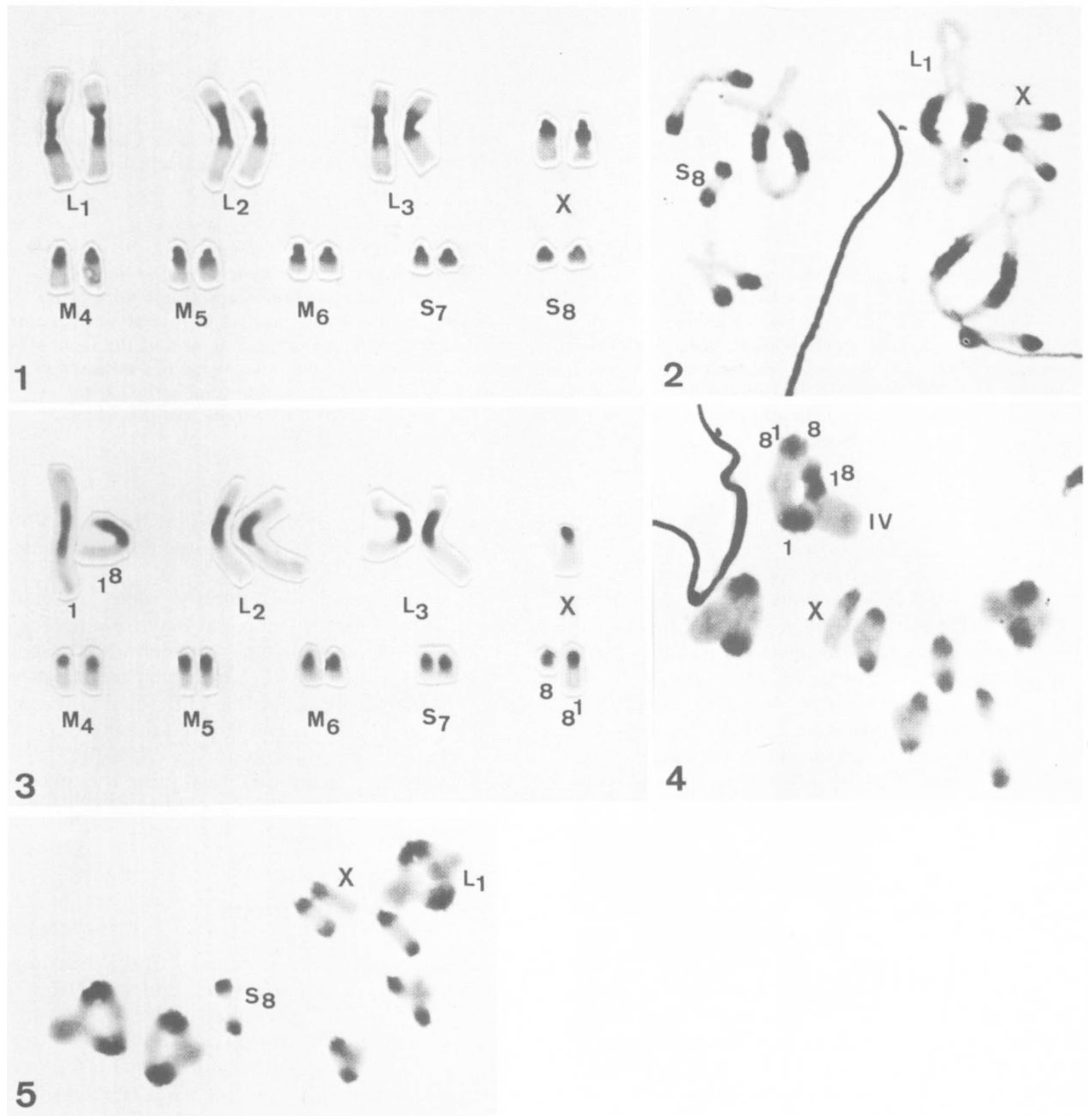

Figures 1-5 C-banded chromosome complement of Stauroderus scalaris in standard individuals (1 and 2$)$ and in the $\mathrm{L}_{1}-\mathrm{S}_{8}$ interchangc mutant (3-5). (1) Female karyotype. (2) Male diplotene cell. (3) Mutant karyotype. (4 and 5) Metaphase I cells from the interchange mosaic male with (4) and without (5) the mutation. Note 4 shows the only ring of four multiple we found. 
$2 n q=16+\mathrm{XX}$, as was reported by Corey (1933). Three autosome pairs are long and submetacentric $\left(\mathrm{L}_{1}-\mathrm{L}_{3}\right)$ and the remaining five pairs are subtelocentric, three being medium $\left(\mathbf{M}_{4}-\mathbf{M}_{6}\right)$ and two short $\left(S_{7}\right.$ and $\left.S_{8}\right)$; the $X$ is longer than the $M_{4}$ but shorter than the $\mathrm{L}_{3}$ chromosome (fig. 1). The presence of extensive paracentromeric heterochromatic segments in all chromosomes of this species has been reported by Corey (1933) and John (1976). Figs. 1 and 2 show not only that all these paracentromeric segments $C$-band positively but additionally that there are no interstitial or distal $C$-bands in the karyotype.

Because the interchange heterozygote male was mosaic for the mutation, we examined each of its 51 testis follicles individually; 28 of these did not carry analyzable spermatocytes. Out of the 23 follicles which could be studied, seven carried the interchange (figs. 3 and 4 ) and 16 were normal (fig. 5). Thus 30 per cent of follicles were heterozygous for the interchange. The interchange involved

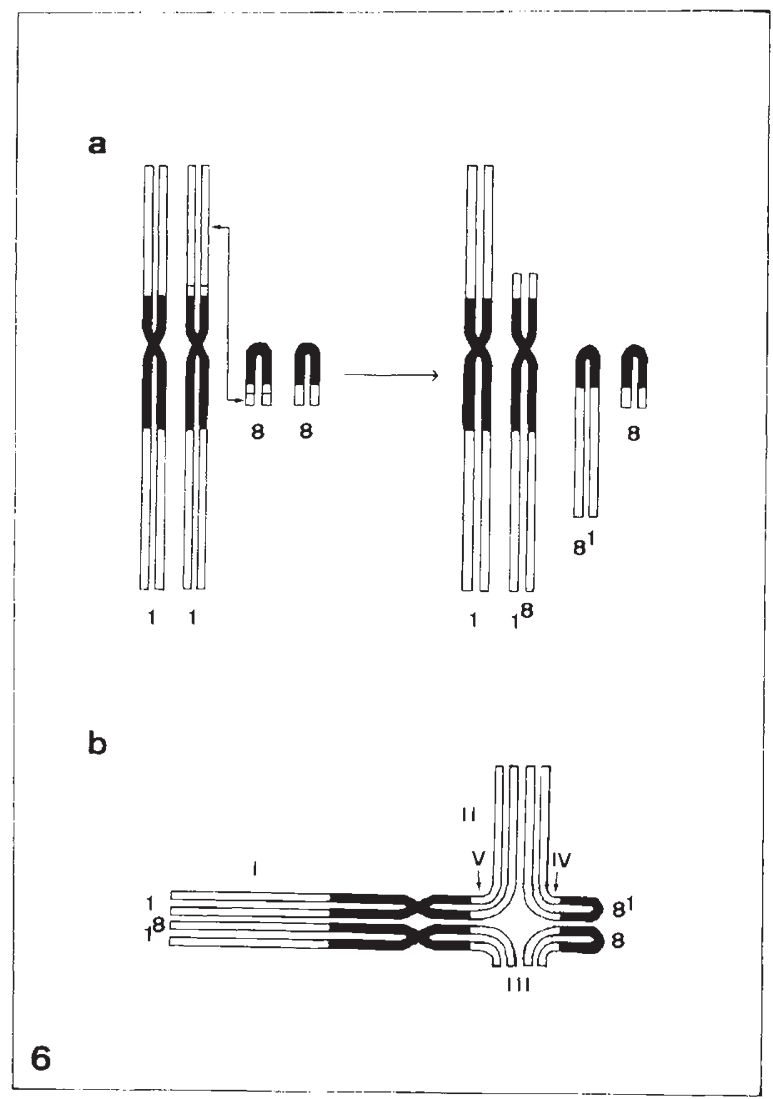

Figure 6 Diagrammatic representation of the $L_{1}-S_{8}$ interchange. (a) Normal (left) and rearranged (right) chromosomes. (b) Expected pairing configuration of the multiple at zygotene. the $\mathrm{L}_{1}$ and the $\mathrm{S}_{8}$ chromosomes, with break points sited in euchromatic zones near the $C$-blocks in both the $S_{8}$ and the short arm of the $L_{1}$ (fig. 6). At zygotene it was possible to detect a very asymmetrical pairing cross (figs. 7-9).

\section{Chiasma interference}

The $C$-banding technique allowed the identification of all four arms of the interchange multiples since the paracentromeric $C$-blocks of $\mathrm{L}_{1}$ are double the size of those of the $S_{8}$. In such multiples it is possible to distinguish five different positions at which chiasmata can form (see fig. 6): Region I, the long arm of $\mathrm{L}_{1}$; Region II, between the break point and the telomere of the short arm of $\mathrm{L}_{1}$; Region III, between the break point and the telomere of $\mathrm{S}_{8}$; Region IV, between the break point and the $C$-block of $S_{8}$; Region $\mathrm{V}$, between the break point and the $C$-block of $\mathrm{L}_{1}$. The interstitial segments (IV and V) are thus effectively very short since chiasmata never form in the $C$-blocks themselves. Examples of chiasma formation in the five regions are shown in fig. 10 and the data from 65 cells are summarised in table 1. Chiasma formation frequently fails in regions III and IV (both corresponding to $S_{8}$ material) so that $\frac{2}{3}$ of the metaphase I cells analysed showed a multiple of three plus one $S_{8}$ univalent (fig. 11). With the single exception of the ring of four multiple shown in fig. 4, only one chiasma forms in either region III or else in region IV in the multiples of four observed. This can be interpreted to imply the existence of intrachromosomal interference between these two regions. There is, however, no evidence for interference between region IV and region II $\left(\mathrm{X}_{(1)}^{2}=\right.$ $0 \cdot 29, P: 0 \cdot 5-0 \cdot 7)$ or between region III and region $\mathrm{V}$, though here it is not possible to apply a contingency $\mathrm{X}^{2}$ test.

We have also tested for the occurrence of interchromosomal chiasma interference using an approach similar to that described by Sybenga (1975) and Arana et al., (1980). At first glance the data of table 2 suggests that a negative correlation might exist between the chiasma frequency of the multiple and that of the six bivalents not involved in the translocation. This was not confirmed by a $\mathrm{X}^{2}$ test, possibly because of the small number of cells sampled. As far as the data go, therefore, there is no demonstrable interchromosomal chiasma interference.

\section{Chiasma frequency}

Table 3 summarises our chiasma scores at metaphase $I$ in the interchange mosaic male (51 mutant 

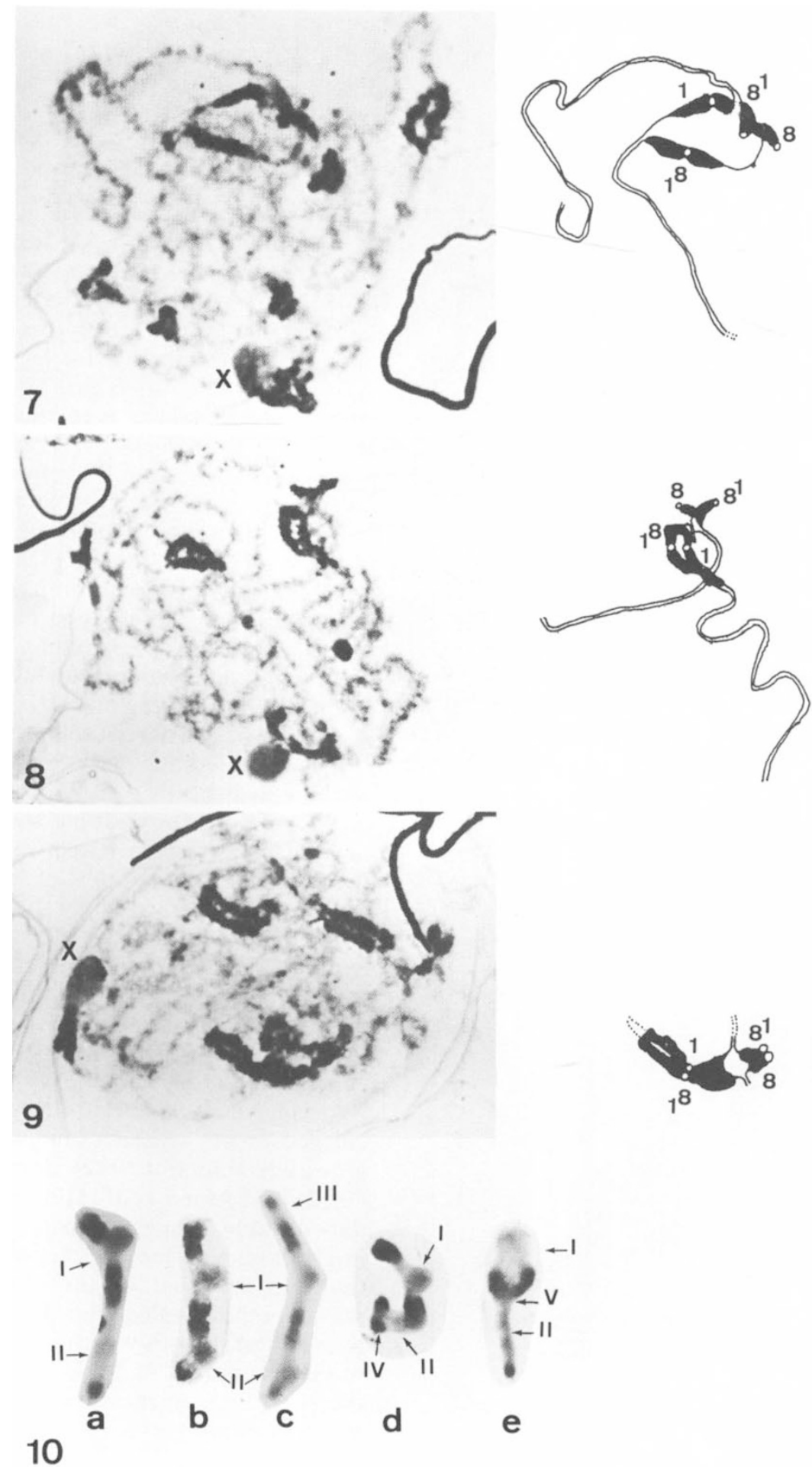

Figures 7-10 Pairing crosses and chiasma formation within them. (7-9) C.-banded zygotene cells showing interchange pairing crosses (left) and an interpretative diagram of them (right). (10) Chiasma formation at metaphase I in the five regions (I-V) of the pairing configurations shown in fig. 6 . 
Table 1 Frequency of chiasma formation, configurations, and co-orientation of multiples in 65 metaphase I cells of $S$. scalaris. C: chain, R: ring configuration

\begin{tabular}{|c|c|c|c|c|c|c|c|}
\hline \multirow[b]{2}{*}{ I } & \multicolumn{4}{|c|}{ Region } & \multirow{2}{*}{$\begin{array}{l}\text { Multiple } \\
\text { configuration }\end{array}$} & \multirow{2}{*}{$\begin{array}{l}\text { Number } \\
\text { of cells }\end{array}$} & \multirow{2}{*}{$\begin{array}{l}\text { Type of } \\
\text { co-orientation }\end{array}$} \\
\hline & II & III & IV & V & & & \\
\hline 1 & 1 & & & & $\mathrm{CIII}+\mathrm{I}$ & 2 & Linear \\
\hline 2 & 1 & & & & $\mathrm{CIII}+\mathrm{I}$ & 17 & Linear \\
\hline 2 & 1 & & & & $\mathrm{CIII}+\mathrm{I}$ & 3 & Adjacent-1 \\
\hline 2 & 1 & & & & $\mathrm{CIII}+\mathrm{I}$ & 5 & Indifferent \\
\hline 2 & 1 & & & & $\mathrm{CIII}+\mathrm{I}$ & 2 & Indistinguishable \\
\hline 2 & 2 & & & & $\mathrm{CIII}+\mathrm{I}$ & 7 & Linear \\
\hline 2 & 2 & & & & $\mathrm{CIII}+\mathrm{I}$ & 2 & Adjacent-1 \\
\hline 3 & 1 & & & & $\mathrm{CIII}+\mathrm{I}$ & 1 & Linear \\
\hline 2 & 1 & & & 1 & $\mathrm{CIII}+\mathrm{I}$ & 1 & Indifferent \\
\hline 2 & 1 & & & 1 & $\mathrm{CIII}+\mathrm{I}$ & 1 & Adjacent-1 \\
\hline 1 & 1 & 1 & & & CIV & 1 & Adjacent-1 \\
\hline 2 & 1 & 1 & & & CIV & 4 & Adjacent-1 \\
\hline 2 & 1 & 1 & & & CIV & 2 & Adjacent-2 \\
\hline 2 & 1 & 1 & 1 & & RIV & 1 & Adjacent-1 \\
\hline 2 & 2 & 1 & & & CIV & 1 & Adjacent-l \\
\hline 1 & 1 & & 1 & & CIV & 2 & Adjacent-1 \\
\hline 2 & 1 & & 1 & & CIV & 2 & Adjacent-1 \\
\hline 2 & 1 & & 1 & & CIV & 6 & Indistinguishable \\
\hline 2 & 2 & & 1 & & CIV & 5 & Adjacent-1 \\
\hline
\end{tabular}

Table 2 Correlation between chiasma frequency in the multiple and that in the six bivalents not involved in the $\mathrm{L}_{1}-\mathrm{S}_{8}$ interchange

\begin{tabular}{|c|c|c|c|c|c|c|c|}
\hline \multirow{2}{*}{$\begin{array}{l}\text { Number of } \\
\text { chiasmata } \\
\text { in the multiple }\end{array}$} & \multicolumn{6}{|c|}{ Number of chiasmata in the six remainder bivalents } & \multirow[b]{2}{*}{ Mean } \\
\hline & 9 & 10 & 11 & 12 & 13 & Total & \\
\hline 2 & & & 2 & & & 2 & $11 \cdot 00$ \\
\hline 3 & 1 & $6(9 \cdot 92)$ & $6(6 \cdot 04)$ & $7(4 \cdot 75)$ & 2 & 22 & $11 \cdot 14$ \\
\hline 4 & & $12(9 \cdot 02)$ & $4(5 \cdot 49)$ & $4(4 \cdot 31)$ & & 20 & $10 \cdot 60$ \\
\hline 5 & & 5 & 2 & & & 7 & $10 \cdot 2.9$ \\
\hline Total & 1 & 23 & 14 & 11 & 2 & 51 & \\
\hline
\end{tabular}

$\mathrm{X}_{2}^{2}=4.026 \quad \mathrm{P}: 0 \cdot 1-0.2 \quad r=-0.323 \quad t=2 \cdot 389 \quad \mathrm{P}: 0.02-0.05$

In brackets: expected values under the independence hypothesis

Table 3 Mean chiasma frequency $(\bar{x})$ and standard error $(\varepsilon)$ in different chromosomes and chromosome regions from the mosaic male (1-4) and from ten standard males (5)

\begin{tabular}{|c|c|c|c|c|c|c|c|c|c|c|c|c|}
\hline \multirow[b]{2}{*}{ Cell type } & \multirow[b]{2}{*}{$N$} & \multicolumn{2}{|c|}{$\begin{array}{l}\text { Region I } \\
\left(\mathrm{L}_{1} \text { long arm) }\right.\end{array}$} & \multicolumn{2}{|c|}{$\begin{array}{l}\text { Regions II + V } \\
\left(\mathrm{L}_{1} \text { short arm }\right)\end{array}$} & \multicolumn{2}{|c|}{$\begin{array}{l}\text { Regions III + IV } \\
\left(\mathrm{S}_{8}\right)\end{array}$} & \multicolumn{2}{|c|}{$\begin{array}{l}\text { Total multiple } \\
\left(\mathrm{L}_{1}+\mathrm{S}_{8}\right)\end{array}$} & \multicolumn{2}{|c|}{$\begin{array}{l}\text { Six remainder } \\
\text { bivalents }\end{array}$} & Total cell \\
\hline & & $\bar{x}$ & $\varepsilon$ & $\bar{x}$ & $\varepsilon$ & $\bar{x}$ & $\varepsilon$ & $\bar{x}$ & $\varepsilon$ & $\bar{x}$ & $\varepsilon$ & $\bar{x} \quad \varepsilon$ \\
\hline $\begin{array}{l}1 \text { Multiples of three } \\
\text { plus univalent }\end{array}$ & 34 & 1.9705 & 0.0514 & $1 \cdot 3235$ & 0.0814 & $0 \cdot 0000$ & $0 \cdot 0000$ & $3 \cdot 2941$ & 0.0992 & $11 \cdot 0588$ & $0 \cdot 1685$ & $14.3235 \quad 0.1777$ \\
\hline $\begin{array}{l}2 \text { Multiples } \\
\text { of four }\end{array}$ & 17 & $1 \cdot 8823$ & $0 \cdot 0805$ & $1 \cdot 3529$ & 0.1194 & I. 0588 & 0.0588 & $4 \cdot 2941$ & 0.1663 & $10 \cdot 2941$ & $0 \cdot 1425$ & $14.5882 \quad 0.2434$ \\
\hline $\begin{array}{l}3 \text { All types of } \\
\text { multiples }\end{array}$ & 51 & 1.9411 & 0.0434 & $1 \cdot 3333$ & 0.0666 & $0 \cdot 3529$ & 0.0731 & $3 \cdot 6274$ & $0 \cdot 1083$ & $10 \cdot 8039$ & 0.1314 & $14.41170 \cdot 1432$ \\
\hline 4 Normal & 44 & $2 \cdot 1136$ & 0.0483 & $1 \cdot 2272$ & 0.0639 & $1 \cdot 0000$ & 0.0000 & $4 \cdot 3409$ & 0.0856 & $10.659 \mathrm{I}$ & $0 \cdot 1214$ & $15 \cdot 00000 \cdot 1751$ \\
\hline $\begin{array}{l}5 \text { Standard } \\
\text { males }\end{array}$ & 100 & $2 \cdot 2400$ & 0.0452 & $1 \cdot 3700$ & 0.0485 & 1.0000 & 0.0000 & $4 \cdot 6100$ & 0.0634 & $10 \cdot 3300$ & 0.0900 & $14.9500 \quad 0 \cdot 1192$ \\
\hline
\end{tabular}


Table 4 A series of Student $t$-tests applied to the data in table 3

\begin{tabular}{|c|c|c|c|c|c|c|c|c|c|c|c|c|}
\hline \multirow[b]{2}{*}{ Comparison } & \multicolumn{2}{|c|}{$\begin{array}{l}\text { Region I } \\
(\mathrm{L}, \text { long arm })\end{array}$} & \multicolumn{2}{|c|}{$\begin{array}{l}\text { Region } \mathrm{II}+\mathrm{V} \\
\left(\mathrm{L}_{1} \text { short arm }\right)\end{array}$} & \multicolumn{2}{|c|}{$\begin{array}{l}\text { Regions III + IV } \\
\left(\mathrm{S}_{8}\right)\end{array}$} & \multicolumn{2}{|c|}{$\begin{array}{l}\text { Total multiple } \\
\left(L_{1}+S_{8}\right)\end{array}$} & \multicolumn{2}{|c|}{$\begin{array}{l}\text { Six remainder } \\
\text { bivalents }\end{array}$} & \multicolumn{2}{|c|}{ Total cell } \\
\hline & $t$ & $\mathrm{P}$ & $t$ & $\mathrm{P}$ & $t$ & $\mathbf{P}$ & $t$ & $\mathrm{P}$ & $t$ & $\mathrm{P}$ & $t$ & $\mathbf{P}$ \\
\hline 1 vs. 2 & 0.92 & $0 \cdot 30-0 \cdot 50$ & $0 \cdot 20$ & $0 \cdot 70-0 \cdot 90$ & $18 \cdot 01$ & $<0.001$ & $5 \cdot 16$ & $<0.001$ & 3.47 & $0.001-0.01$ & $0 \cdot 88$ & $0 \cdot 30-0 \cdot 50$ \\
\hline l vs. 4 & $2 \cdot 03$ & $0 \cdot 02-0.05$ & 0.93 & $0 \cdot 30-0 \cdot 50$ & $\infty$ & 0 & $7 \cdot 99$ & $<0 \cdot 001$ & 1.92 & $0 \cdot 05-0 \cdot 10$ & $2 \cdot 71$ & $0.001-0.01$ \\
\hline 2 vs. 4 & $2 \cdot 46$ & $0.01-0.02$ & 0.93 & $0 \cdot 30-0 \cdot 50$ & $1 \cdot 00$ & $0 \cdot 20-0 \cdot 40$ & $0 \cdot 25$ & $0 \cdot 70-0 \cdot 90$ & 1.95 & $0 \cdot 05-0 \cdot 10$ & $1 \cdot 37$ & $0 \cdot 10-0 \cdot 20$ \\
\hline 3 vs. 4 & $2 \cdot 66$ & $0.001-0.01$ & $1 \cdot 15$ & $0 \cdot 20-0 \cdot 30$ & $8 \cdot 85$ & $<0 \cdot 001$ & $5 \cdot 17$ & $<0.001$ & 0.81 & $0 \cdot 30-0 \cdot 50$ & $2 \cdot 60$ & $0 \cdot 01-0 \cdot 05$ \\
\hline 4 vs. 5 & 1.91 & $0.05-0 \cdot 10$ & $1 \cdot 78$ & $0 \cdot 05-0 \cdot 10$ & 0 & $1 \cdot 00$ & $2 \cdot 53$ & $0 \cdot 01-0.02$ & $2 \cdot 18$ & $0.02-0.05$ & $0 \cdot 24$ & $0 \cdot 70-0 \cdot 90$ \\
\hline
\end{tabular}
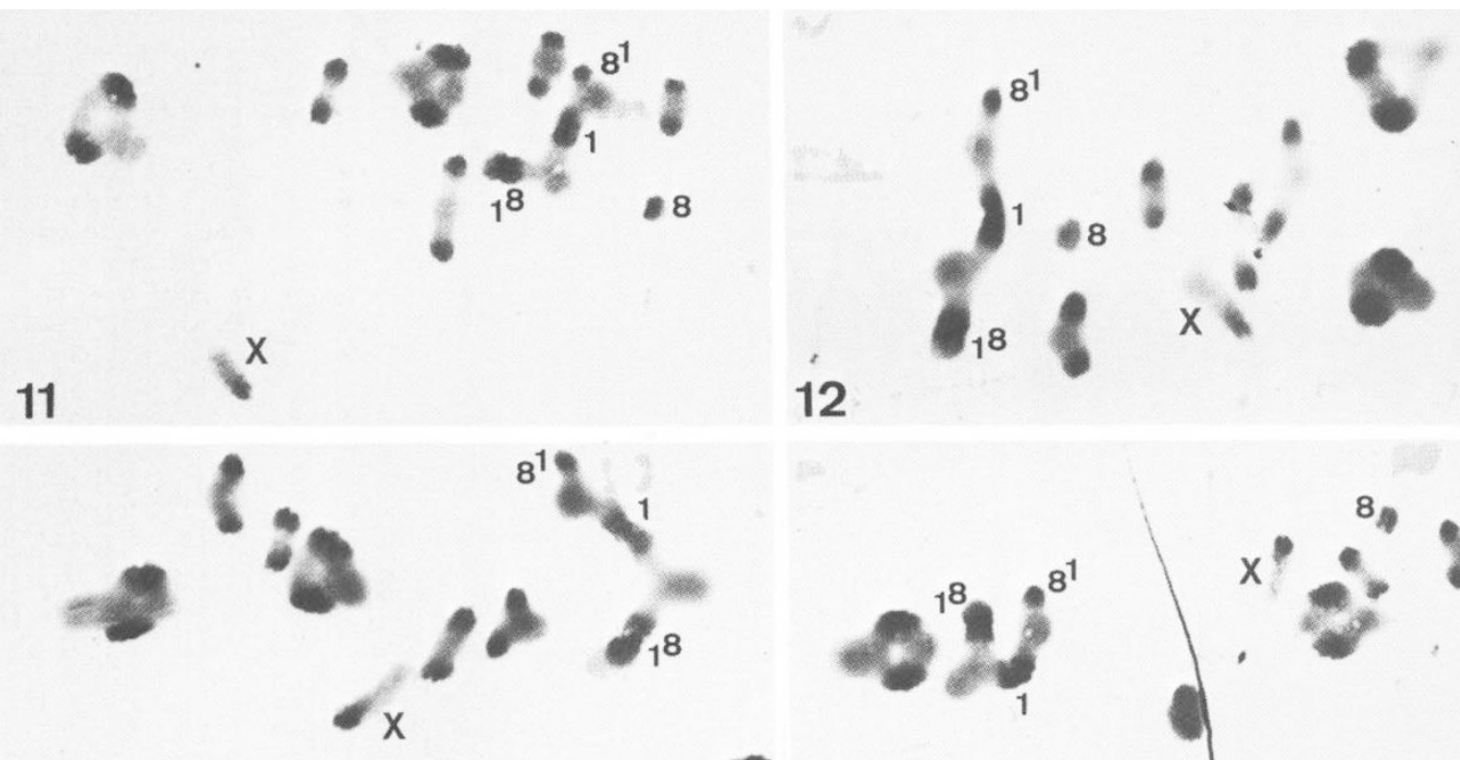

13
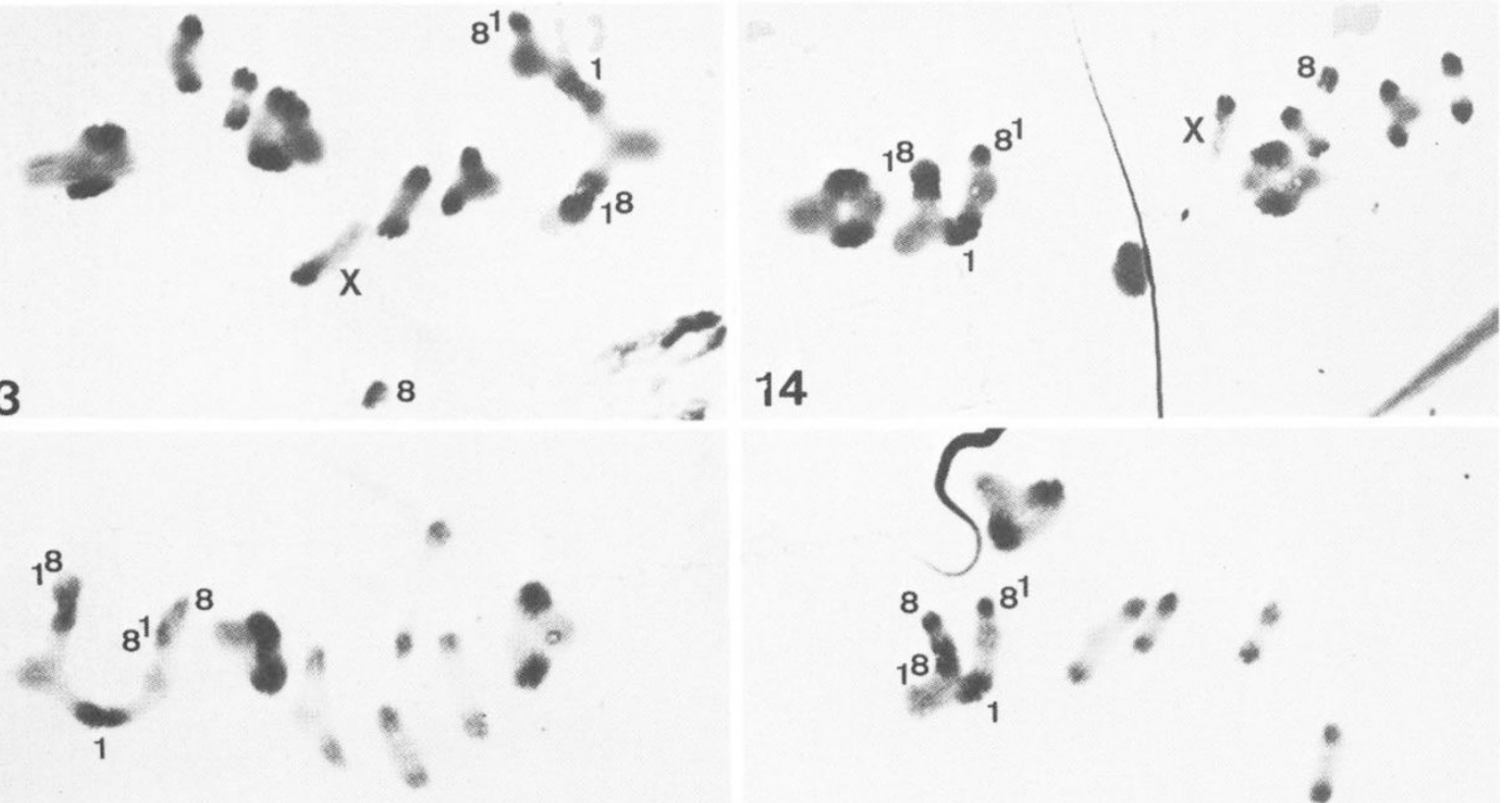

15
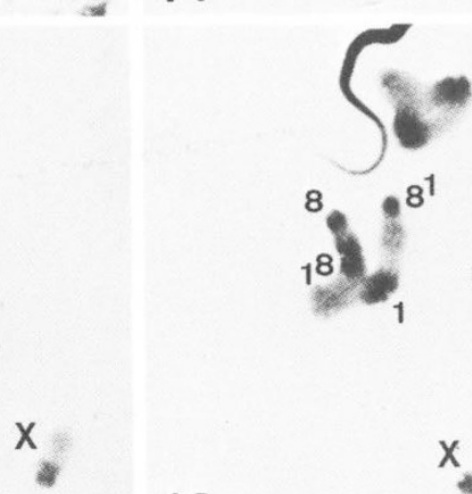

16

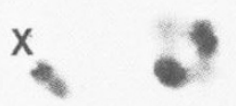

Figures 11-16 C-banded metaphase I cells showing different multiple configurations and their orientation. (11 and 12) Chains of three in indifferent and linear orientation. (13) Chain of three in adjacent-1 orientation. (14) Chain of three in convergent orientation. (15 and 16) Chains of four in adjacent-1 (15) and adjacent-2 (16) orientation. 
and 44 normal cells) and in 10 normal males ( 10 cells from each one). Table 4 shows a series of comparisons of these mean chiasma frequencies using Student $t$ tests. From these data we conclude that: 1) In cells showing a CIII+I configuration there is, as expected, a significant decrease of chiasma frequency in the multiple compared to CIV configurations. This, however, is paralleled by a significant increase of chiasma frequency in the remaining bivalents, so that total chiasma frequency is similar in both types of cells. 2) A comparison of mutant cells carrying a $\mathrm{CIII+I}$ configuration with normal cells of the mosaic male demonstrate that the multiple-containing cells, which lack chiasmata in the $S_{8}$, also show a significant decrease in chiasma frequency of the long arm of the $\mathrm{L}_{1}$. This leads to a significant reduction in the chiasma frequency of both the multiple and the cell. Mutant cells with multiples of four also show a significant decrease in the chiasma frequency of the long $\operatorname{arm}$ of $\mathrm{L}_{1}$. Consequently, a comparison between normal cells and mutant cells of the mosaic carrying multiples of either three or four demonstrates that the latter show a significant decrease in the chiasma frequency of the long arm of the $L_{1}$, in the $S_{8}$ and in total multiple and total cell values. 3) Normal cells of the mutant mosaic male show a chiasma frequency in the bivalents involved in the interchange $\left(\mathrm{L}_{1}\right.$ and $\left.\mathrm{S}_{8}\right)$ which is significantly lower than that of the standard males. Since the $\mathrm{S}_{8}$ bivalent always forms one chiasma in both cell types, this difference is exclusively due to a reduction of chiasma frequency in the $\mathrm{L}_{1}$ bivalent. Paralleling this there is a significant increase in the chiasma frequency of the six remaining bivalents which compensates for the reduction, so that both types of cells show similar total chiasma frequencies.

\section{Centromere co-orientation and fertility}

As table 1 shows, in all cells analysed the orientation of the chromosomes involved in the multiples would be expected to lead to the formation of unbalanced gametes and a consequent loss in fertility. Chains of three were either linear (fig. 12) or indifferent (figs. 11, 13 and 14) while chains of four most frequently showed adjacent-1 (fig. 15) and only rarely adjacent-2 (fig. 16) orientation.

\section{DISCUSSION}

The mosaic male of Stauroderus scalaris reported in this paper would not have inherited the mutation from its parents. The interchange presumably originated de novo during testis development.

Chiasma formation in the different regions of the multiples confirms that the interchange involved breaks in the euchromatin near the $C$ blocks of the $S_{8}$ and the short arm of the $L_{1}$. In many organisms it has been shown that translocations frequently involve breaks in or adjacent to heterochromatin (Barton, 1951; John and Lewis, 1958, 1965; Kihlman, 1966; Natarajan and Ahnström, 1969; Bloom, 1974). This preponderance of breaks in the vicinity of heterochromatin has been explained by the close physical association of non-homologous heterochromatic regions in chromocenters or in polarised chromosome configurations (Lea, 1955; Evans and Bigger, 1961). In $S$. scalaris, however, the heterochromatic blocks rarely associate in either pre-meiotic interphase or in leptotene nuclei (John, 1976). If this is also true of spermatogonial cells this would imply that this interchange has arisen independently of any polarisation process.

The extreme size difference of the chromosomes involved in the $S$. scalaris interchange determines that the multiple pairing cross is very asymmetrical, showing two very long and two very short arms. This asymmetry ensures the prevalence of non-homologous, adjacent-1, orientation in chains of four. This, in turn, can be explained by assuming that the orientation behaviour between two adjacent centromeres in a multiple at metaphase $\mathbf{I}$ is related to the distance between them (Lewis and John, 1963; Arana et al., 1980). The $\mathrm{S}_{8}$ centromeres thus orientate to opposite poles whenever a chiasma forms in the interstitial segment formed by region IV. This would necessarily preclude adjacent-2 orientation (McClintock, 1945; Burnham, 1950, 1956; Lewis and John, 1963; Wise and Rickards, 1977; Arana et al., 1980, 1982). Thus in the only two cells showing adjacent-2 orientation there was no chiasma in region IV. Furthermore, in multiples of three, in which chiasmata failed in both regions III and IV, the 8-univalent always passed to the opposite pole to that to which the $8^{1}$ chromosome in the multiple was oriented. Consequently adjacent- 2 orientation in our mutant male of $S$. scalaris is excluded not only by chiasma formation in the interstitial segments, which is really not very frequent, but also by preferential migration of the 8 and the $8^{\prime}$ chromosomes to opposite poles even when they are not associated by a chiasma.

The effect of the interchanges on chiasma formation properties can be unambiguously analysed in individuals which are mosaic, because here nor- 
mal cells may be compared with mutant ones within the same testis so that genotypic influences on chiasma comparisons can be discounted. The $\mathrm{S}_{8}$ bivalent in $S$. scalaris always forms only one chiasma. Regions III and IV of the multiples of four, both of which include $S_{8}$ material, usually compete for the formation of this single chiasma. The only exception was one ring multiple of four (see fig. 4) in which both regions contained one chiasma. This exceptional behaviour pattern can be explained by assuming that while the short euchromatic region of the $S_{8}$ bivalent, which includes regions III and IV, can potentially form only one chiasma, the change of part of this region (III) to the $\mathrm{L}_{1}$ chromosome has led to a greater probability of formation of two chiasmata. On the other hand, chiasmata failed frequently (66 per cent of cells) in regions III and IV so giving rise to multiples of three plus one $S_{8}$ univalent. No interference could be demonstrated between either of these regions and those adjacent to them ( $\mathrm{V}$ and II, respectively). Apart from their shortness, chiasma failure in these regions might be explained by the fact that, as John (1976) demonstrated, the paracentromeric blocks of $S$. scalaris are the last chromosome regions to pair during zygotene. Our fig. 7 shows that $C$-heterochromatic blocks of the pairing cross can indeed be unpaired. Such behaviour might well cause a failure of crossing over in regions III, IV and V.

The reduction of chiasma frequency in the $S_{8}$ regions giving rise to multiples of three plus one $\mathrm{S}_{8}$ univalent is parallelled by an increase in chiasma frequency of the six bivalents not involved in the interchange. So, cells with a multiple of three plus a univalent show one chiasma less in the multiple but 0.76 chiasmata more in the six remaining bivalents than do cells with a multiple of four. Overall, therefore, there is no difference between both types of cells for mean total cell chiasma frequency. Similar interchromosomal effects of interchanges on chiasma formation have been reported in the grasshoppers Cibolacris parviceps (Hewitt, 1967) and Euchorthippus pulvinatus gallicus (Arana et al., 1980). In both these cases, however, comparisons were made between one mutant heterozygote and several normal individuals so that the possibility that the observed differences are caused by genetic variation cannot be excluded (Arana et al., 1980). In the mutant male of $S$. scalaris, which is mosaic for the interchange, chiasma comparisons were made between cells with the same genotype, so that all the observable differences must result from the interchange itself.
Interchromosomal effects on chiasma frequency have been explained by assuming a lengthening of meiotic prophase in heterozygotes, so leading to an increase in the time available for crossing over (Lucchesi and Suzuki, 1968). In $S$. scalaris, the increase in chiasma frequency of the bivalents in multiple containing cells is associated with the presence of a $S_{8}$ univalent, because it was observed only in cells with CIII + I configurations. We suggest, therefore, that in this case the mechanism of interchromosomal chiasma effects may be explained on the following hypothesis. Genotypic control regulates the number of chiasmata in the cells of each individual, grouping them around a mean value. The mechanism which regulates chiasma formation also implies a dependence of the number of crossing overs on the time available for their formation, as Lucchesi and Suzuki (loc cit.,) claim. The regulatory system is constrained by the necessity to form a minimum of one chiasma in each of the bivalents in a cell to insure their correct segregation at anaphase I. If as a result of pairing failure of the $C$-blocks in the multiple chiasma formation fails in the $S_{8}$ material, then the regulatory mechanism might extend the time available for crossing over in an attempt to ensure one chiasma in the $S_{8}$. During this extension an opportunity exists for the remaining bivalents to form additional chiasmata. If, on the other hand, there is full pairing of the $C$-blocks, as shown in figs. 8 and 9 , then chiasmata are soon formed in the four arms of the pairing cross giving rise to multiples of four. Under these circumstances the regulatory signal for the termination of crossing over would occur sooner so leading to a lower number of crossover points in the six remaining bivalents.

Acknowledgements We would like to thank Professor Bernard John for the critical reading of the manuscript.

\section{REFERENCES}

ARANA, 1', SANTOS, I. 1. ANI) (IIRALDEZ, R. 1980. Chiasma interference and centromere co-orientation in a spontaneous translocation heterozygote of Euchorthippus pulvinatus gallicus (Acrididae: Orthoptera). Chromosoma, 78, $327-340$.

ARANA, P., SANTOS, J. L., HENRIQUES-GIL, N. AND GIRALIMIZ, R. 1982. Centromere co-orientation in a spontaneous translocation heterozygote of Euchorthippus pulvinatus gallicus (Acrididae, Orthoptera). Genetica, 58, 81-84.

BARION, D. W., 1951. Localised chiasmata in the differentiated chromosomes of the tomato. Genetics, 36, 374-381.

BLOOM, w. I.., 1974. Origin of reciprocal translocations and their effect in Clarkia speciosa. Chromosoma, 49, 61-76. 
BURNHAM, C. R., 1950. Chromosome segregation involving chromosome 6 in maize. Genetics, 35, 446-481.

BURNHAM, C. R., 1956. Chromosome interchanges in plants. Bot. Rev., 22, 419-557.

Burnham, C. R., 1962. Discussions in cytogenetics. Bugges Publ. Co. Minneapolis, Minn.

COREY, H. I., 1933. Chromosome studies in Stauroderus (an Orthopteran). J. Morph., 55, 313-347.

EVANS, H. J. AND BIGGER, T. R. L. 1961. Chromatid aberrations induced by gamma irradiation. II. Nonrandomness in the distribution of chromatid aberrations in relation to chromosome length in Vicia faba root-tip cells. Genetics, $46,277-289$.

GOSALVEZ, J., LOPEZ-FERNANDEZ, C. AND GARCIA. LAFUENTE, R. 1982. A spontaneous translocation heterozygote involving centromere regions in Gomphocerus sibiricus (L) (Orthoptera: Acrididae). Chromosoma, 86, 49-57.

HEWITT, G. M., 1967. An interchange which raises chiasma frequency. Chromosoma, 21, 285-295.

HEWITT, G. M., 1979. Grasshoppers and Crickets. Animal Cytogenetics vol. 3: Insecta 1 Orthoptera, Gebrüder Borntraeger, Berlin-Stuttgart.

JOHN, B., 1976. Myths and mechanisms of meiosis. Chromosoma, 54, 295-325.

JOHN, B. 1983. The role of chromosome change in the evolution of orthopteroid insects. In: Chromosomes in evolution of eukaryotic groups vol. 1. Sharma, A. K. and Sharma, A. Eds., C. R. C. Press Inc., Boca Raton, Florida, 1-110.
JOHN, B. AND LEWIS, K. R. 1958. Studies on Periplaneta americana. III. Selection for heterozygosity. Heredity, 12, 185-197.

JOHN, B. AND LEWIS, K. R. 1965. The meiotic system. Protoplasmatologia VI, F1, 1-335, Springer-Verlag, Wien.

KIHLMAN, B. A., 1966. Actions of chemicals on dividing cells. Prentice-Hall, Englewood Cliffs, N.J.

LEA, D. E., 1955. Actions of radiations on living cells. Cambridge Univ. Press. Cambridge.

LEWIS, K. R. AND JOHN, B. 1963. Spontaneous interchange in Chorthippus brunneus. Chromosoma, 14, 618-637.

LUCCHESI, J. C. AND SUZUKI, D. T. 1968. The interchromosomal control of recombination. Ann. Rev. Genet., 2, 53-86.

MCCLINTOCK, B., 1945. Neurospora. I. Preliminary observations of the chromosomes of Neurospora crassa. Amer. J. Bot., 32, 671-678.

NATARAJAN, A. T. AND AHNSTRÖM, G. 1969. Heterochromatin and chromosome aberrations. Chromosoma, 28, 48-61.

SYBEnGA. J. 1972. General Cytogenetics. North-Holland Publishing Company, Amsterdam.

SYBENGA, J. 1975. Meitoc configurations. Monogr. on theor. appl. Genet. vol. 1. Springer, Berlin-Heidelberg-New York.

WHITE, M. J. D. 1963. Cytogenetics of the grasshopper Moraba scurra. VIII. A complex spontaneous translocation. Chromosoma, 14, 140-145.

WISE, D. AND RICKARDS, G. K. 1977. A quadrivalent studied in living and fixed grasshopper spermatocytes. Chromosoma, 63, 305-315. 